\title{
Experimental Investigation of Mechanical Properties on Kevlar and Flax Fiber Reinforced Hybrid Composite Material with Filler Material
}

\author{
M. Jaya Prakash, Dr.B.V.Ramana Murty
}

\begin{abstract}
The recent modern technologies need materials with combined properties like high strength to weight ratio, high stiffness, high corrosion resistance, high fatigue strength, high dimensional stability, etc., these can't be met by the traditional metal alloys. Composites made by Polymeric materials are reinforced with natural and synthetic fibers have high stiffness and strength to weight ratio as compared to traditional materials. The current work primarily describes the improvement of mechanical properties of hybrid composite consists of woven kevlar29 laminate and woven flax laminate reinforced with epoxy with and without filler material. The effect of filler material has been studied for different percentages of aluminium $2.7 \%, 5.4 \%$, and $8 \%$ by weight. Specimens are made as per ASTM standards by using hand lay-up technique. Experiments are conducted to investigate mechanical properties such as tensile, compression, flexural, toughness, and hardness. Results obtained from the above tests are very encouraging due to the addition of filler material in natural and synthetic fiber reinforced hybrid composites. It has been observed that the mechanical proprieties are increasing with increase of composition of filler material.
\end{abstract}

Index Terms - Hybrid Composites, Flax Fiber, Filler Material, Kevlar.

\section{INTRODUCTION}

The research mainly focused on flax fiber composites due to their superior mechanical properties and chemical modifications. The synthetic fiber Kevlar fabricated for reaching the demand for industrial and improved-technology applications. However, the cost of Kevlar fiber is high when compared to natural fiber flax. Shahirul et al. [1] conducted Indentation and impact tests on woven E-glass with flax and jute which are formed with sandwich-like and intercalation. Maheswaran et al. [2] studied the fracture behavior of the Kevlar/Glass-Epoxy Hybrid Composite using finite element analysis and experimental method. Ou et al. [3] used Kevlar fibers grafted by functional silane and allyl and used as

Manuscript revised June 7, 2019 and published on July 10, 2019 M. Jaya Prakash, PG student, Department of Mechanical Engineering, Gayatri Vidya Parishad College of Engineering (A), Visakhapatnam, India. Dr.B.V.Ramana Murty, Professor, Department of Mechanical Engineering, Gayatri Vidya Parishad College of Engineering (A), Visakhapatnam, India. reinforcements in Wood-Flour/High-Density-Polyethylene composites to improve the mechanical properties. Foruzanmehr et al. [4] used modified $\mathrm{TiO} 2$ grafted flax fibers to reinforce polylactic acid (PLA) composites. Murali et al [5] used natural fibers Sisal, banana and jute reinforced with epoxy for manufacturing helmet. Mursalin et al. [6] studied the flexural properties of the composites fabricated by reinforcing bagasse, coir and banana fiber with epoxy resin matrix.

\section{EXPERIMENTAL INVESTIGATION}

\subsection{Materials}

The Two Reinforcement materials used are Synthetic Material as woven Kevlar 29 fiber and Natural Plant Fiber as woven Flax fiber and Matrix used in this hybrid composite is Epoxy LY556 (Araldite) with combination of Hardener HY951 (Aradur) in 10:1 (E:H) ratio along with addition of aluminium filler material with different proportions i.e. 5, 10, and 15 grams.

Table 1: No of layers and weight of each fiber.

\begin{tabular}{|c|c|c|c|c|}
\hline Fibers & $\begin{array}{c}\text { No of } \\
\text { layers of } \\
\text { fibers }\end{array}$ & $\begin{array}{c}\text { Weight } \\
\text { of the } \\
\text { fibers in } \\
\text { grams }\end{array}$ & $\begin{array}{c}\text { Weight } \\
\text { of the } \\
\text { resin in } \\
\text { grams }\end{array}$ & $\begin{array}{c}\text { Desired } \\
\text { thicknes } \\
\text { s mm }\end{array}$ \\
\hline $\begin{array}{c}\text { Hybrid } \\
\text { (flax+kevlar) }\end{array}$ & $3+3$ & 53 & 121 & 3 \\
\hline $\begin{array}{c}\text { Hybrid } \\
\text { (flax+Kevlar+ } \\
\text { Al5 grams) }\end{array}$ & $3+3$ & 53 & 126 & 3 \\
\hline $\begin{array}{c}\text { Hybrid } \\
\text { (flax+Kevlar+ } \\
\text { Al10 grams) }\end{array}$ & $3+3$ & 53 & 131 & 3 \\
\hline $\begin{array}{c}\text { Hybrid } \\
\text { (flax+Kevlar+ } \\
\text { Al15 grams) }\end{array}$ & $3+3$ & 53 & 136 & 3 \\
\hline
\end{tabular}

\subsection{Relative Weights of fiber and resin}

Resin weight is taken by considering fiber manufacturing properties. For woven flax fiber, the weight ratio of fiber and 
resin is 1:3.5 and woven kevlar29 fiber, the weight ratio of fiber and resin is $1: 1$.

\subsection{Composition of hybrid composite materials}

Table 2: Weight percentage of fiber and matrix in the composite.

\begin{tabular}{|l|l|l|}
\hline S.No & Specimen name & $\begin{array}{l}\text { Composition of composite } \\
\text { by (wt \%) }\end{array}$ \\
\hline $\mathbf{1}$ & Hybrid(flax+kevlar) & $\begin{array}{l}\text { Flax }(15.5 \%)+\text { Kevlar } \\
(14.9 \%)+\text { Epoxy }(69.5 \%)\end{array}$ \\
\hline $\mathbf{2}$ & $\begin{array}{l}\text { Hybrid with Al 5 } \\
\text { grams }\end{array}$ & $\begin{array}{l}\text { Flax }(15 \%)+\text { Kevlar }(14.5 \%) \\
\text { + Epoxy }(67.5 \%)+\text { Al }(2.7 \%)\end{array}$ \\
\hline $\mathbf{3}$ & $\begin{array}{l}\text { Hybrid with Al 10 } \\
\text { grams }\end{array}$ & $\begin{array}{l}\text { Flax }(14.6 \%)+\text { Kevlar } \\
(14.1 \%)+\text { Epoxy }(65.7 \%)+ \\
\text { Al }(5.4 \%)\end{array}$ \\
\hline $\mathbf{4}$ & $\begin{array}{l}\text { Hybrid with Al 15 } \\
\text { grams }\end{array}$ & $\begin{array}{l}\text { Flax }(14.2 \%)+\text { Kevlar } \\
(13.7 \%)+\text { Epoxy }(64 \%)+\mathrm{Al} \\
(8 \%)\end{array}$ \\
\hline
\end{tabular}

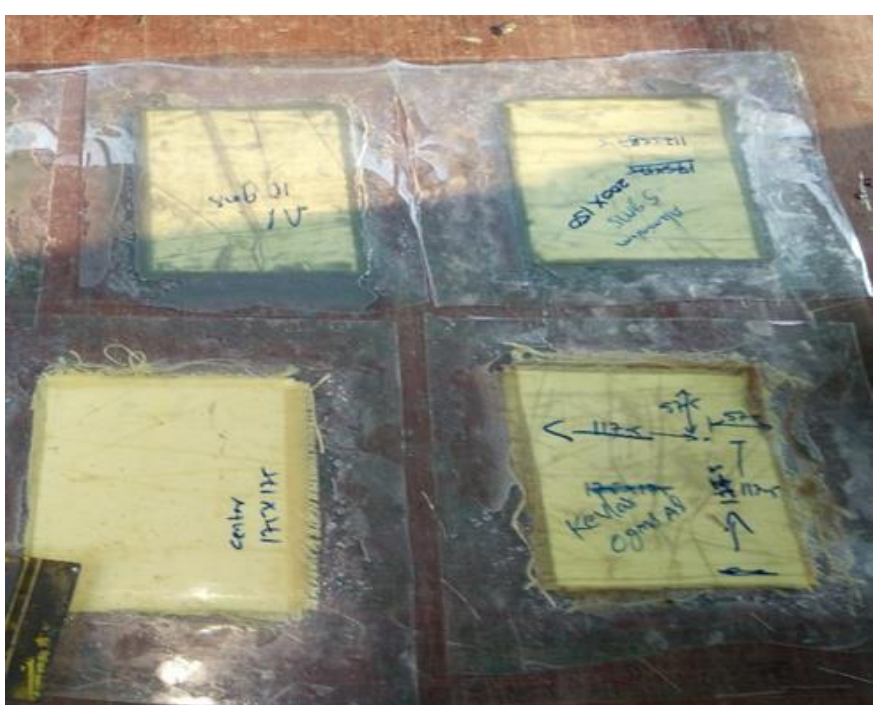

Fig 1: Fabricated hybrid composite materials with varying different proportions of filler material (Al).

\section{MECHANICAL TESTING}

The following tests are to be performed on fabricated hybrid composite material.
1. Tensile test
2. Compression test
3. Flexural test
4. Charpy impact test
5. Brinell's hardness test

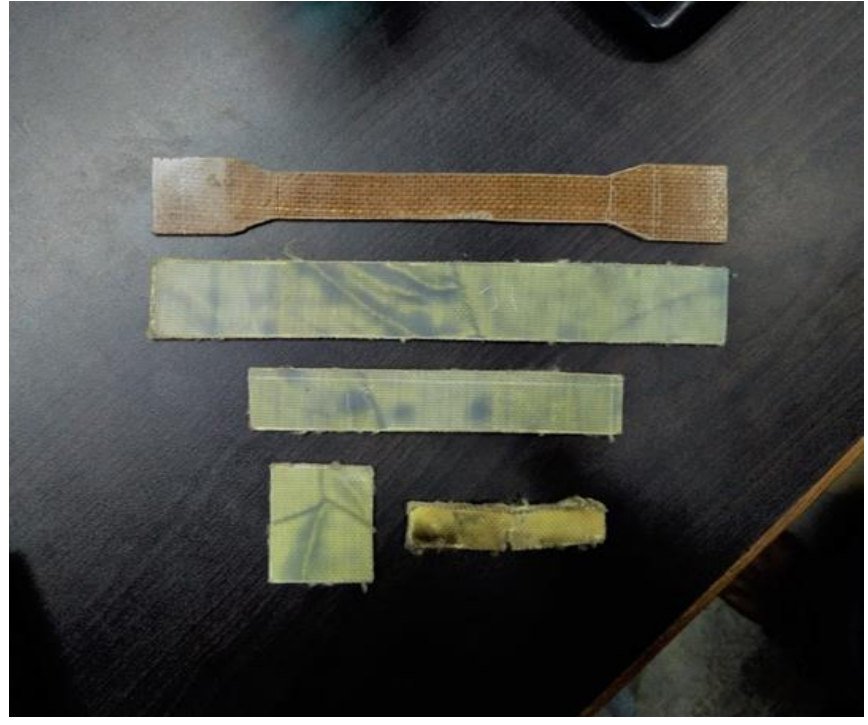

Fig 2: Specimens before testing.

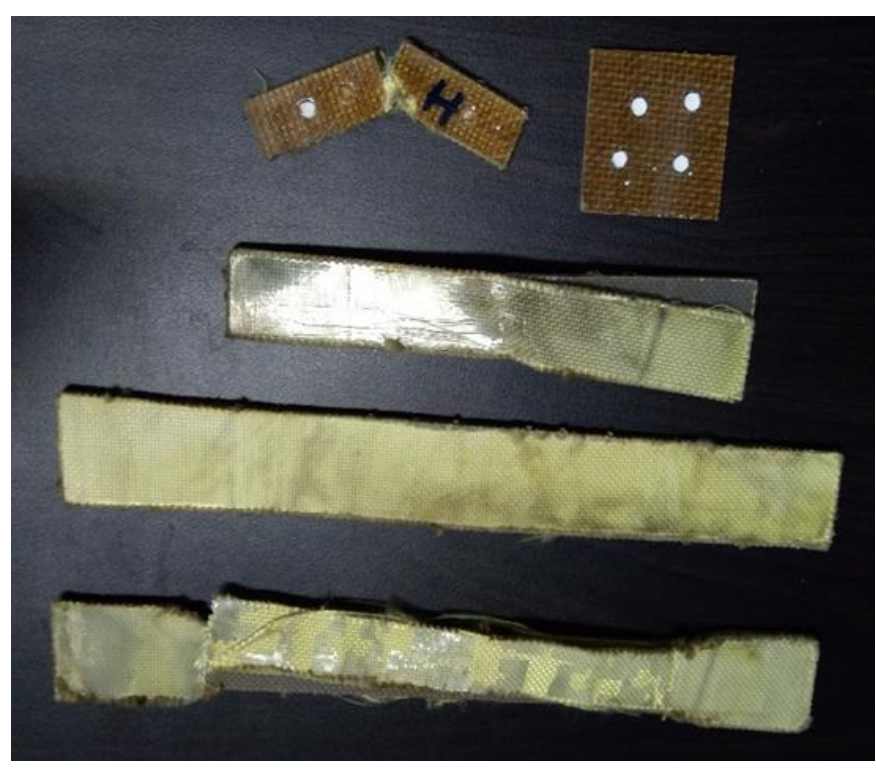

Fig 3: Specimens after testing.

\subsection{Tensile test}

The dog-bone-shaped tensile specimens with a size of $250 \times 25 \times 3 \mathrm{~mm}$ according to ASTM D3039 standard is tested using an INSTRON 8801 testing machine at strain rate of $3 \mathrm{~mm} / \mathrm{min}$. The results are presented in the table 3 .

Table 3: Tensile Test results.

\begin{tabular}{|c|c|c|c|c|c|}
\hline $\begin{array}{l}\mathbf{S} \\
\mathbf{N} \\
\mathbf{O}\end{array}$ & $\begin{array}{l}\text { Specimen } \\
\text { label }\end{array}$ & $\begin{array}{l}\text { Maxim } \\
\text { um } \\
\text { load } \\
(\mathrm{KN})\end{array}$ & $\begin{array}{l}\text { Load } \\
\text { at } \\
\text { break } \\
(\mathrm{KN})\end{array}$ & $\begin{array}{l}\text { Modulus } \\
\text { (E-modul } \\
\text { us) (MPa) }\end{array}$ & $\begin{array}{l}\text { Ultima } \\
\text { te } \\
\text { tensile } \\
\text { strengt } \\
\text { h } \\
\text { (MPa) }\end{array}$ \\
\hline 1 & Hybrid & 5.06 & 3.11 & 4272.16 & 112.35 \\
\hline 2 & $\begin{array}{l}\text { Hybrid } \\
\text { with Al } 5 \\
\text { gms }\end{array}$ & 4.12 & 3.66 & 4555.52 & 91.58 \\
\hline
\end{tabular}




\begin{tabular}{|l|l|l|l|l|l|}
\hline 3 & $\begin{array}{l}\text { Hybrid } \\
\text { with Al 10 } \\
\text { gms }\end{array}$ & 5.02 & 3.12 & 4749.50 & 111.45 \\
\hline 4 & $\begin{array}{l}\text { Hybrid } \\
\text { with Al 15 } \\
\text { gms }\end{array}$ & 6.38 & 4.74 & 4732.09 & 141.71 \\
\hline
\end{tabular}

\subsection{Compression test}

Rectangular shaped compression a specimen with a size of $140 \times 25 \times 3 \mathrm{~mm}$ according to ASTM D3410 is tested using an INSTRON 8801 testing machine. The results are presented in the table 4.

Table 4: Compression Test results.

\begin{tabular}{|c|c|c|c|c|}
\hline S.NO & $\begin{array}{l}\text { Specimen } \\
\text { label }\end{array}$ & $\begin{array}{l}\text { Maximum } \\
\operatorname{load}(\mathbf{N})\end{array}$ & $\begin{array}{l}\text { Modulus } \\
\text { (MPa) }\end{array}$ & $\begin{array}{l}\text { compressive } \\
\text { strength } \\
(\mathrm{MPa})\end{array}$ \\
\hline 1 & Hybrid & 568.63 & 5518.84 & 7.58 \\
\hline 2 & $\begin{array}{l}\text { Hybrid } \\
\text { with Al } 5 \\
\text { gms }\end{array}$ & 619.69 & 5548.60 & 8.26 \\
\hline 3 & $\begin{array}{l}\text { Hybrid } \\
\text { with Al } \\
10 \mathrm{gms}\end{array}$ & 735.93 & 5719.98 & 9.81 \\
\hline 4 & $\begin{array}{l}\text { Hybrid } \\
\text { with Al } \\
15 \mathrm{gms}\end{array}$ & 935.53 & 7076.02 & 12.47 \\
\hline
\end{tabular}

\subsection{Flexural test}

Flexural test has been performed to determine the modulus of rupture. Specimens with dimensions $125 \times 20 \times 3 \mathrm{~mm}$ according to the standard ASTM D709 is tested with 3-point bending test machine using the same mechanical testing machine.

Table 5: Results from flexural test.

\begin{tabular}{|l|l|l|l|l|}
\hline S. & Specimen \\
O & label & $\begin{array}{l}\text { Maxim } \\
\text { um load } \\
\text { (N) }\end{array}$ & $\begin{array}{l}\text { Flexural } \\
\text { stress at } \\
\text { maximum } \\
\text { flexural } \\
\text { load } \\
\text { (MPa) }\end{array}$ & $\begin{array}{l}\text { Modulu } \\
\text { S } \\
\text { (MPa) }\end{array}$ \\
\hline 1 & Hybrid & 219.97 & 154.36 & 6465.14 \\
\hline 2 & $\begin{array}{l}\text { Hybrid with } \\
\text { Al 5 gms }\end{array}$ & 200.51 & 140.71 & 7412.22 \\
\hline 3 & $\begin{array}{l}\text { Hybrid with } \\
\text { Al 10 gms }\end{array}$ & 274.07 & 192.33 & 7754.62 \\
\hline 4 & $\begin{array}{l}\text { Hybrid with } \\
\text { Al 15 gms }\end{array}$ & 275.41 & 193.27 & 7730.81 \\
\hline
\end{tabular}

\subsection{Brinell's hardness test}

Hardness of the specimens was measured with Brinell's hardness testing machine by applying $500 \mathrm{kgf}$ load and using indenter of $5 \mathrm{~mm}$ diameter.

Table 6: Results from hardness test.

\begin{tabular}{|l|l|l|l|l|l|}
\hline S.NO & $\begin{array}{l}\text { Specimen } \\
\text { label }\end{array}$ & $\begin{array}{l}\text { Load } \\
\text { applied } \\
\text { (N) }\end{array}$ & $\begin{array}{l}\text { Diameter } \\
\text { of } \\
\text { indenter } \\
\mathbf{D = 5 m m}\end{array}$ & $\begin{array}{l}\text { Average } \\
\text { diameter of } \\
\text { indentation } \\
\mathbf{d} \text { (mm) }\end{array}$ & $\begin{array}{l}\text { Brinell's } \\
\text { Hardness } \\
\text { Number } \\
\text { (BHN) } \\
\mathbf{K g} / \mathbf{m m}^{2}\end{array}$ \\
\hline 1 & Hybrid & 4905 & 5 & 3.73 & 38.13 \\
\hline 2 & $\begin{array}{l}\text { Hybrid } \\
\text { with Al 5 } \\
\text { gms }\end{array}$ & 4905 & 5 & 4 & 31.84 \\
\hline 3 & $\begin{array}{l}\text { Hybrid } \\
\text { with Al } \\
10 \text { gms }\end{array}$ & 4905 & 5 & 3.93 & 33.36 \\
\hline 4 & $\begin{array}{l}\text { Hybrid } \\
\text { with Al } \\
15 \text { gms }\end{array}$ & 4905 & 5 & 3.7 & 38.90 \\
\hline
\end{tabular}

\subsection{Charpy impact test}

Impact strength was calculated for specimens measuring $63.5 \times 12.7 \times 3 \mathrm{~mm}$ using a notched impact testing instrument as per ASTM D256 standard.

Table 7: Results from impact test.

\begin{tabular}{|l|l|l|l|l|l|l|l|}
\hline & $\begin{array}{l}\text { Cross } \\
\text { sectio } \\
\text { nal } \\
\text { area } \\
\text { belo } \\
\text { w the } \\
\text { notch } \\
\mathbf{S m m}^{2} \\
\mathbf{N} \\
\mathbf{O}\end{array}$ & $\begin{array}{l}\text { Speci } \\
\text { en } \\
\text { label } \\
\text { lial } \\
\text { ene } \\
\text { rgy } \\
(\mathbf{J})\end{array}$ & $\begin{array}{l}\text { Rea } \\
\text { ding } \\
\text { after } \\
\text { impa } \\
\text { ct } \mathbf{J})\end{array}$ & $\begin{array}{l}\text { Err } \\
\text { or in } \\
\text { read } \\
\text { ing } \\
(\mathbf{J})\end{array}$ & $\begin{array}{l}\text { Act } \\
\text { ual } \\
\text { ene } \\
\text { rgy } \\
(\mathbf{J})\end{array}$ & $\begin{array}{l}\text { Tough } \\
\text { ness } \\
\mathbf{J} / \mathbf{m m}^{2}\end{array}$ \\
\hline 1 & Hybrid & 18 & 300 & -12 & -6 & 282 & 15.66 \\
\hline 2 & $\begin{array}{l}\text { Hybrid } \\
\text { with Al } \\
5 \text { gms }\end{array}$ & 18 & 300 & -11 & -6 & 283 & 15.72 \\
\hline 3 & $\begin{array}{l}\text { Hybrid } \\
\text { with Al } \\
10 \text { gms }\end{array}$ & 24 & 300 & -13 & -6 & 281 & 11.70 \\
\hline 4 & $\begin{array}{l}\text { Hybrid } \\
\text { with Al } \\
15 \text { gms }\end{array}$ & 21 & 300 & -10 & -6 & 284 & 11.83 \\
\hline
\end{tabular}

\section{RESULTS}

The results obtained by various tests are presented in the form of Bar charts from fig 4 to fig 10. 
International Journal of Research in Advent Technology, Vol.7, No.6, June 2019

E-ISSN: 2321-9637

Available online at www.ijrat.org

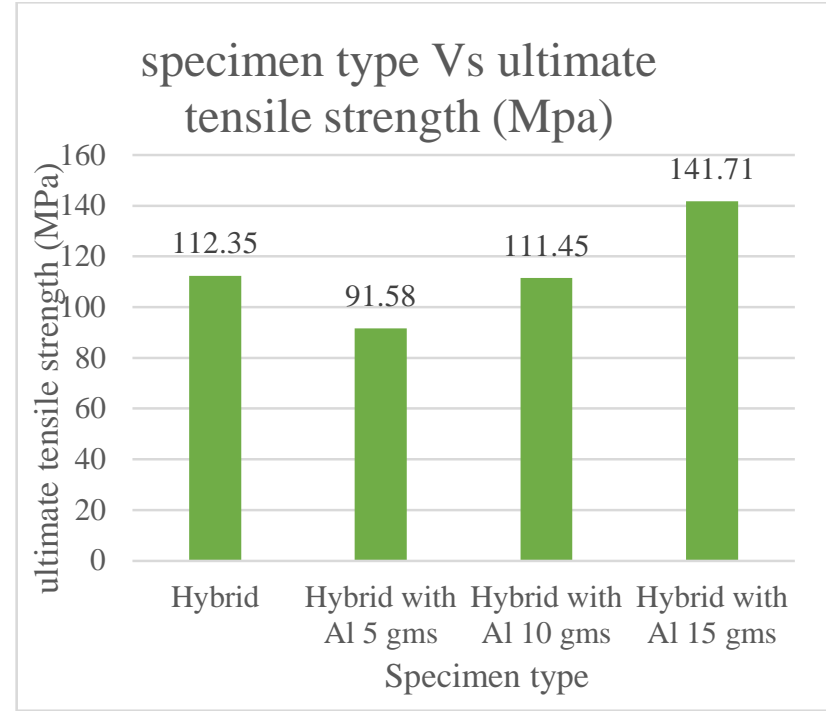

Fig 4: Plot between specimen type and Tensile strength.

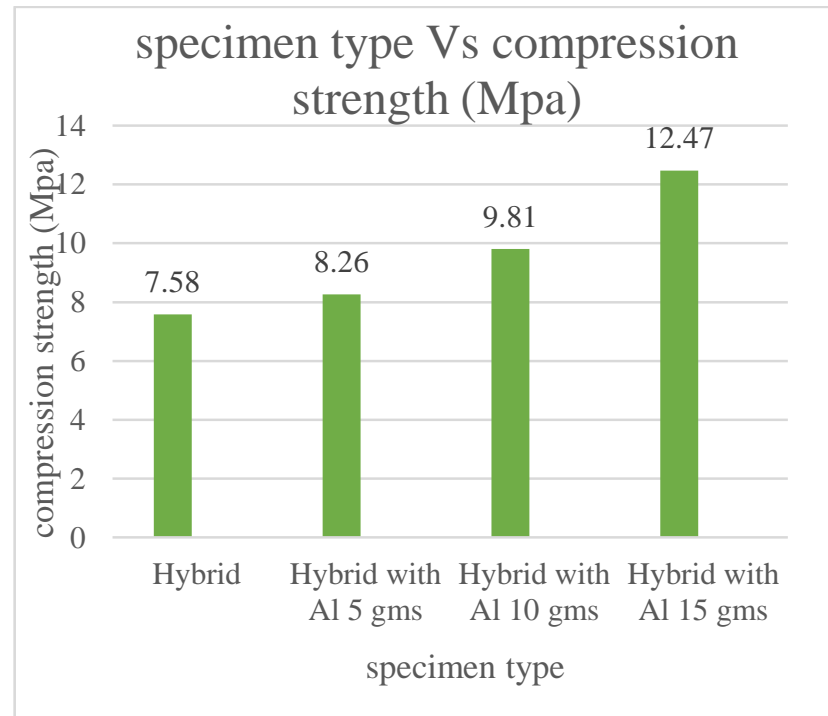

Fig 5: Plot between specimen type and compressive strength.

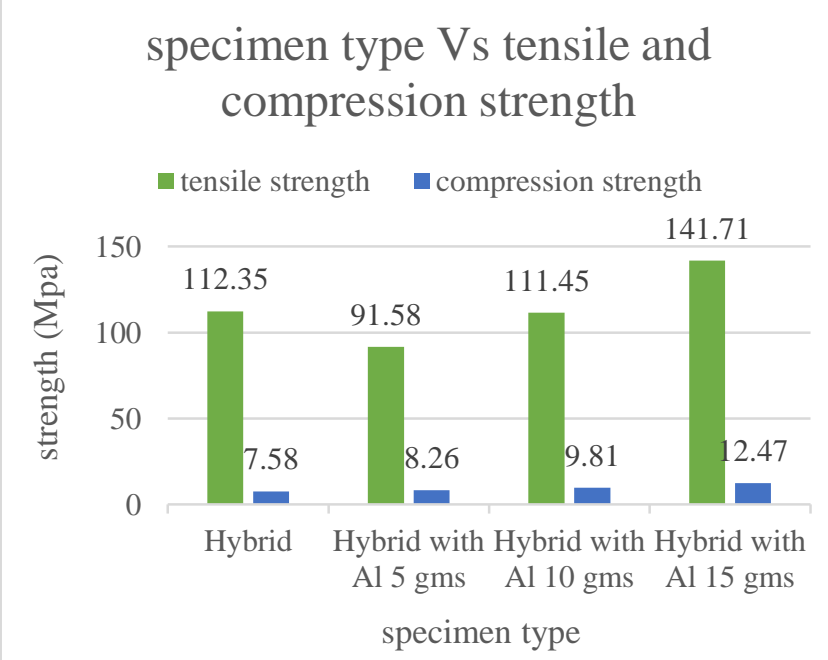

Fig 6: Plot between specimen type and relative tensile and compression strengths.

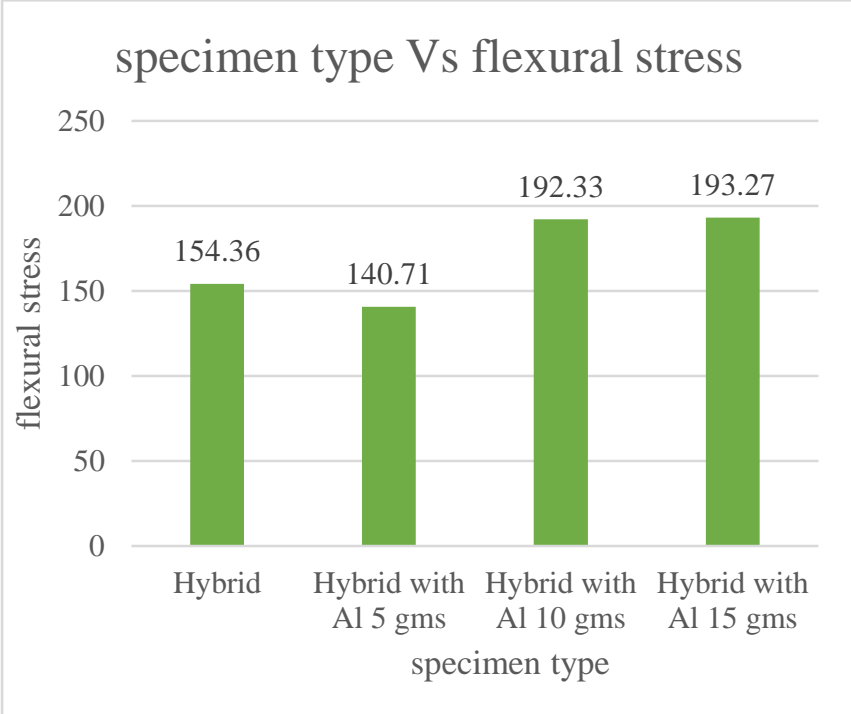

Fig 7: Plot between specimen type and flexural stress.

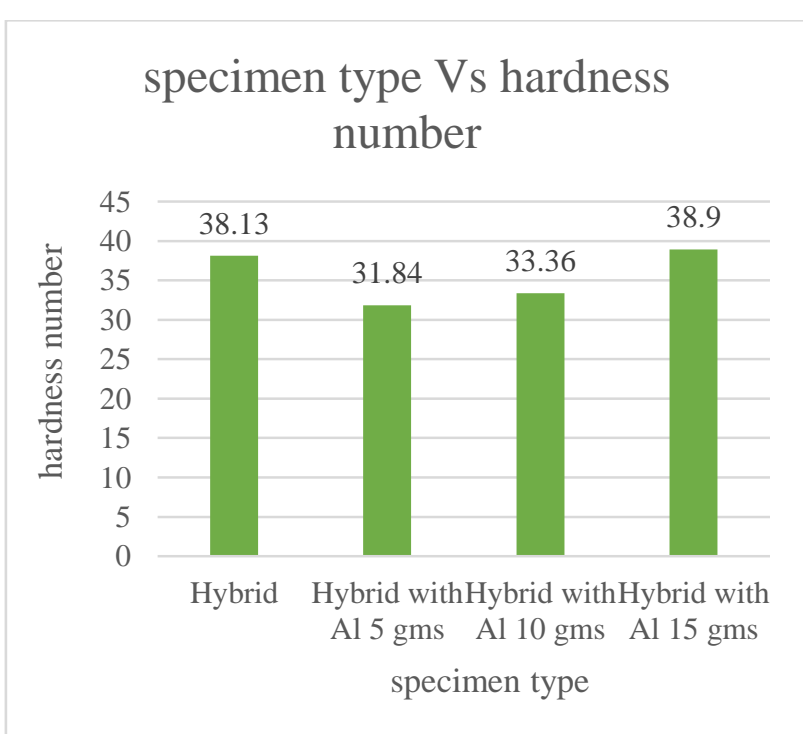

Fig 8: Plot between specimen type and hardness number.

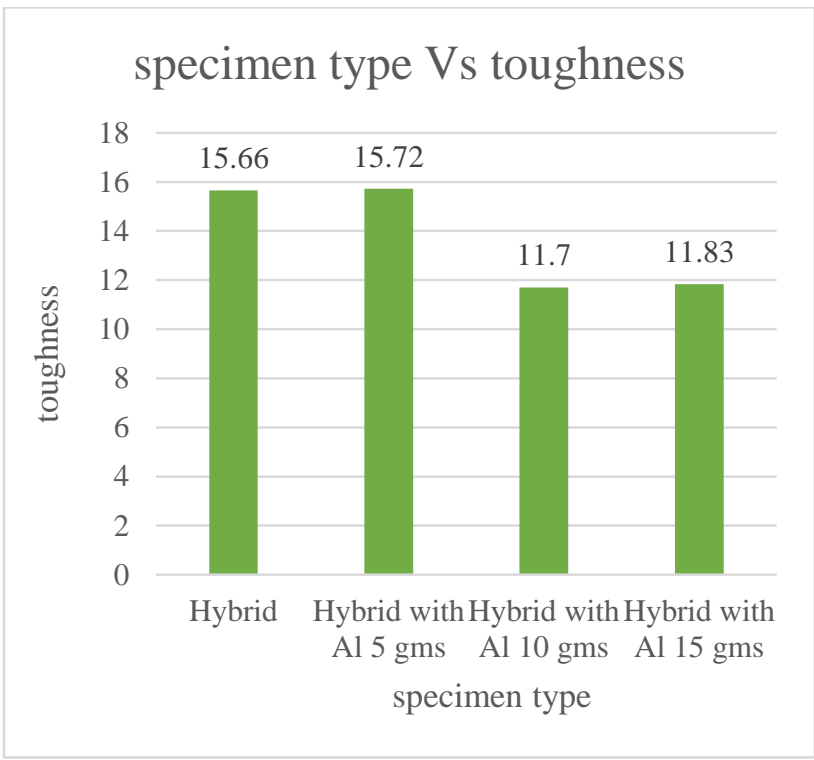

Fig 9: Plot between specimen type and toughness. 


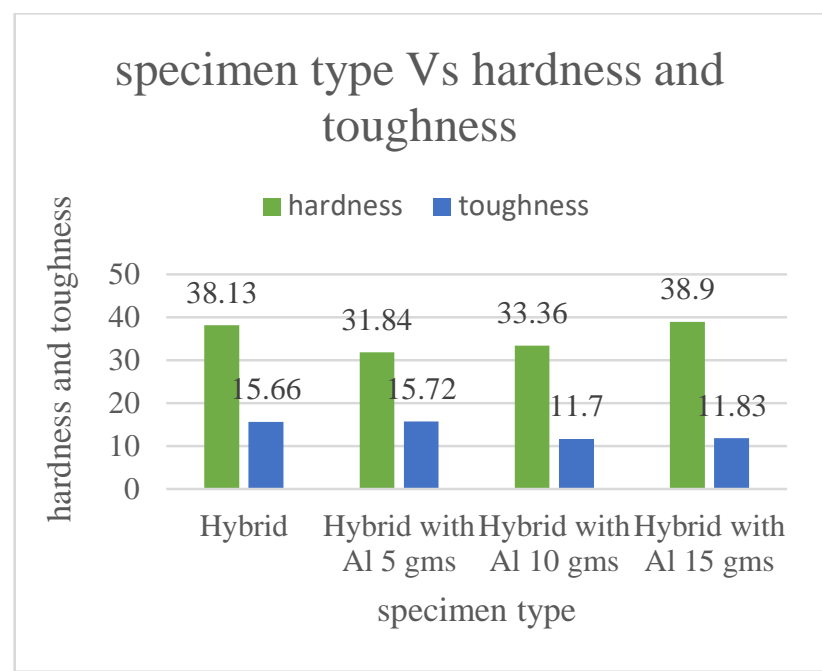

Fig 10: Plot between specimen type and relative hardness and toughness.

\section{DISCUSSIONS}

- From the figure 4 it has been observed that as the percentage of filler material increases the tensile strength is increasing in hybrid composite.

- From the figure 5 the compression strength of hybrid composite increases with the increase of the percentage of filler material.

- From the figure 7 it is evident that the flexural stress decreases for hybrid composite containing 5 grams of filler material and by increasing the filler material more than 5 grams the flexural stress increases.

- From the figure 8 Kevlar has high brinell's hardness number compared to other composite materials.

- $\quad$ From the figure 9 it clearly shows that by addition of filler material into hybrid composite the toughness decreases.

\section{CONCLUSIONS}

- From this work it is evident that, hybrid composite materials have higher strength as compared to the natural composite materials.

- Hybrid composite materials are more economical as compared to the synthetic fiber reinforced composite materials.

- The properties of the natural fibers can be improved by combining with synthetic fibers. It also reduces the cost.

- The properties of these hybrid composite materials are

\section{AUTHORS PROFILE}

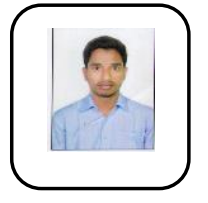

M. Jaya Prakash is presently pursuing PG belongs to department of mechanical engineering, gayatri vidya parishad college of engineering (A), Visakhapatnam, Andhra pradesh. His area of interest is mechanics of composite materials. He have published few papers in journals.

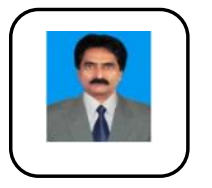

Dr.B.V.Ramana Murty is presently working as Dean and professor in department of mechanical engineering, gayatri vidya Parishad College of engineering (A), Visakhapatnam, Andhra pradesh. His area of interest is manufacturing and design. He have published numerous papers in conferences and journals. He have 30 years of teaching experience and 17 years of administrative experience. He guided $3 \mathrm{Ph} . \mathrm{D}$. Scholars. further improved by addition of optimal proportion of filler material.

\section{REFERENCES}

[1] Muhamad Shahirul Bin Mat Jusoh, Haris Ahmad Bin Israr Ahmad, Mohd Yazid bin Yahya, "Indentation and Low Velocity Impact Properties of Woven E-glass Hybridization with Basalt, Jute and Flax Toughened Epoxy Composites", $3^{\text {rd }}$ Interntaional Conference On Power Generation Systems and Renewable Energy Technologies, 2017, pp.164-168.

[2] Ming Cheng, Weinong Chen, Tusit Weerasooriya, "Experimental Investigation of the Transverse Mechanical Properties of a Single Kevlar KM2 Fiber", International Journal of Solids and Structures, 2004, Vol.41, pp. 6215-6232.

[3] J. Maheswaran, T. Velmurugan, M. Mohammed Mohaideen, "An Experimental and Numerical Study of Fracture Toughness of Kevlar-Glass Epoxy Hybrid Composite", International Conference on Energy Efficient Technologies for Sustainability, 2013, pp.936-942.

[4] Rongxian Ou, Hui Zhao, Shujuan Sui, Yongming Song, Qingwen Wang, "Reinforcing effects of Kevlar fiber on the mechanical properties of wood-flour/high-density polyethylene composites", Composites: part A, 2010, Vol.41, pp.1272-1278.

[5] Christophe Baley, Camille Goudenhooft, Patrick Perre, Pin Lub, Floran Pierre, Alain Bourmaud, "Compressive strength of flax fiber bundles within the stem and comparison with unidirectional flax/epoxy composites", Industrial Crops \& Products, 2018, Vol.130, pp.25-33.

[6] Soo-Jin Park, Min-Kang Seo, Tae-Jun Ma, Douk-Rae Lee, "Effect of Chemical Treatment of Kevlar Fibers on Mechanical Interfacial Properties of Composites", Journal of Colloid and Interface Science, 2002, Vol.252, pp.249-255.

[7] MReza Foruzanmehr, Pascal Y. Vuillaume, Said Elkoun, Mathieu Robert, "Physical and Mechanical Properties of PLA Composites Reinforced by TiO2 Grafted Flax Fibers"', Materials and Design, 2016, Vol.106, pp.295-304.

[8] Murali.B, Nagarani.J, "Design and Fabrication of Construction Helmet by Using Hybrid Composite Material", International Conference on Energy Efficient Technologies for Sustainability, 2013, pp.145-147.

[9] Mondher Haggui, Abderrahim El Mahi, Zouhaier Jendli, Ali Akrout, Mohamed Haddar, "Static and Fatigue Characterization of Flax Fiber Reinforced Thermoplastic Composites by Acoustic Emission", Applied Acoustics, 2018, Vol.147, pp.100-110.

[10] Rifatul Mursalin, Md. Wahedul Islam, Md. Moniruzzaman, Md. Ferdous Zaman, Muhammad Azmain Abdullah, "Fabrication and Characterization of Natural Fiber Composite Material", International Conference On Computer, Communication, Chemical, Material and Electronic Engineering of Engineering Research and Technology, 2018, pp.1-4.

[11] Antoine Barbulee, Moussa Gomina, "Variability of the mechanical properties among flax fiber bundles and strands", $3^{\text {rd }}$ International Conference on Natural Fibers: Advanced Materials for a Greener World, ICNF, 2017, vol.200, pp.487-493. 